\title{
Pembelajaran inkuiri terbimbing tentang cermin datar untuk siswa SMP
}

\author{
Eni Setyowati, Sutopo*, Vita Ria Mustikasari \\ Universitas Negeri Malang, Jl. Semarang No. 5 Malang, Jawa Timur, Indonesia \\ *Penulis korespondensi, Surel: sutopo.fisika@um.ac.id
}

Paper received: 01-02-2021; revised: 15-02-2021; accepted: 28-02-2021

\begin{abstract}
This study aims to determine the use of guided inquiry learning to understanding students' concept about image formation by flat mirror. This study uses a mixed method research of embedded experimental design. The research subject was 88 students of Private Junior High School in the city of Malang. Then, results showed that learning can improve students' understanding of the concept well $(\mathrm{d}$ - effect size $=2.32$ and $\mathrm{N}$-gain $=0.47)$.
\end{abstract}

Keywords: guided inquiry; flat mirror; the understanding of the concept

\begin{abstract}
Abstrak
Penelitian ini bertujuan untuk mengetahui efektifas pembelajaran inkuiri terbimbing terhadap pemahaman konsep siswa tentang cermin datar. Penelitian ini menggunakan metode penelitian mixed method jenis embedded experimental model. Subjek penelitian sebanyak 88 siswa di salah satu SMP swasta di kota Malang. Hasil penelitian menunjukkan, pembelajaran dapat meningkatan pemahaman konsep siswa dengan baik (d-effect size $=2,32$ dan N-gain 0,47).
\end{abstract}

Kata kunci: inkuiri terbimbing; cermin datar; pemahaman konsep

\section{Pendahuluan}

Salah satu tujuan belajar sains adalah menguasai ide-ide pokok dalam sains (NRC, 2012). Siswa dikatakan memahami konsep dalam sains jika mampu memahami, mengaplikasikan serta mampu mengkomunikasikan suatu konsep (Hamdani dkk, 2012). Pemahaman konsep yang sudah dimiliki siswa dapat digunakan untuk memahami fenomena alam yang berkaitan dengan konsep tersebut (Hamdani dkk, 2012; Rustaman, 2005).

Perilaku cahaya banyak berkaitan dengan kehidupan sehari-hari siswa. Beberapa contoh fenomena perilaku cahaya seperti terbentuknya pelangi, pembentukan bayangan ketika bercermin, dan proses melihat pada manusia. Pemahaman yang baik tentang perilaku cahaya seperti perambatan cahaya dengan menggunakan prinsip pemantulan dan pembiasan sangat diperlukan untuk memahami fenomena sehari-hari dan berbagai aplikasi teknologinya (Sutopo, 2014).

Beberapa penelitian menunjukkan banyak siswa mengalami kesulitan dalam memahami konsep cahaya khususnya subbab cermin datar yang terdiri dari fenomena pembentukan bayangan pada cermin datar dan jumlah bayangan yang dibentuk dua cermin datar yang membentuk sudut. Kesulitan siswa memahami konsep yaitu pada: (1) mengaitkan hukum pemantulan dengan terjadinya bayangan pada cermin datar; (2) menentukan posisi bayangan pada cermin datar karena sebagian siswa masih berpendapat bahwa posisi bayangan yang dibentuk oleh cermin datar tergantung pada posisi pengamat (Sutopo, 2014; Agnes,2015); (3) memahami makna/istilah dalam IPA seperti "maya/nyata", yang digunakan untuk menamai sifat bayangan yang terbentuk, banyak siswa yang menganggap bayangan yang dibentuk pada cermin datar bersifat nyata (Saputri, 2015). 
Penelitian yang sudah dilakukan untuk meningkatkan pemahaman siswa pada konsep cahaya yaitu penelitian Umrotun (2012) yang menekankan pada penggunaan inkuiri terbimbing dapat meningkatkan pemahaman konsep siswa. Hal ini dapat dinyatakan dengan meningkatnya hasil belajar yang dicapai siswa dari siklus I dengan nilai rata-rata 77 menjadi 86 pada siklus II, dan meningkatnya nilai $\mathrm{N}$-Gain antara siklus I dan silus II sebesar 0,2169 $(21,69 \%)$. Namun penelitian tersebut tidak mendeskripsikan proses pembelajaran secara konkrit, sehigga kurang dapat diaplikasikan pada proses pembelajaran dikelas. Maka diperlukan penelitian dengan pendeskripsian jelas proses pembelajaran inkuiri terbimbing yang dapat meningkatkan pemahaman konsep siswa.

Pembelajaran inkuiri dikembangkan agar siswa dapat menemukan dan menggunakan berbagai sumber informasi dan ide-ide untuk meningkatkan pemahaman mereka tentang masalah, topik atau isu tertentu (Abidin, 2014). Pembelajaran inkuiri juga dapat meningkatkan kemampuan bekerja ilmiah dan meningkatkan pemahaman konsep (Slack, 2007). Tingkatan inkuiri menurut Wenning (2005) yaitu Discovery Learning, Interactive Demonstration, Inquiry Lesson, Inquiry Lab (Guided Inquiry, Bounded Inquiry dan Free Inquiry), dan Hypothetical Inquiry. Salah satu tingkatan dalan inkuiri yaitu inkuiri terbimbing (Guided Inquiry) yang berarti dalam tahapan proses tertentu, siswa tetap mendapatkan bimbingan dan panduan dari guru dalam melaksanakan proses inkuirinya (Abidin, 2014).

Kemampuan-kemampuan penting dalam pembelajaran sains menurut NRC (2012) yaitu (1) mengajukan pertanyaan; (2) mengembangkan dan menggunakan model; (3) merencanakan dan melakukan penyelidikan; (4) menganalisis dan menginterpretasi data; (5) berfikir matematis; (6) membangun gagasan; (7) memperkuat argumen berdasarkan dari fakta/bukti; (8) evaluasi dan mengkomunikasikan. Berbagai komponen tersebut tidak semua dapat diaplikasikan dalam proses pembelajaran. Proses pembelajaran perilaku cahaya bertujuan untuk memahami fenomena sehari-hari dan mengaplikasikan dalam teknologi. Materi perilaku cahaya termasuk materi yang berhubungan dengan perambatan, pemantulan dan pembiasan cahaya. Sehingga proses pembelajaran selain untuk meningkatkan pemahaman konsep perilaku cahaya juga harus dapat meningkatkan kerja ilmiah siswa.

Untuk mencapai tujuan pembelajaran tersebut dikembangkan kembali urutan proses pembelajaran dari National Research Council (2012) dan aspek inkuiri terbimbing yang diharapkan selain dapat meningkatkan pemahaman konsep juga meningkatkan kerja ilmiah siswa. Urutan proses pembelajaran yaitu (1) mengamati fenomena, (2) merumuskan masalah, (3) merumuskan jawaban pertanyaan, (4) merumuskan penjelasan, (5) menghubungkan dengan pengetahuan ilmiah, (6) mengkomunikasikan dan penguatan. Oleh karena itu, penelitian ini bertujuan untuk melihat seberapa efektif pembelajaran yang dilakukan di kelas.

\section{Metode}

Penelitian ini bertujuan untuk mengetahui pengaruh pembelajaran inkuiri terbimbing pada subbab cermin datar terhadap pemahaman konsep siswa. Pemahaman konsep siswa dapat dilihat dari hasil pretest dan posttest. Pretest digunakan untuk mengetahui kemampuan awal siswa pada materi cermin datar. Sedangkan posttest digunakan untuk mengetahui pemahaman siswa setelah pembelajaran. Sesuai dengan tujuan penelitian tersebut, penelitian ini menggunakan metode kuantitatif dan kualitatif (mixed methods) jenis embedded experimental model (Creswell \& Clark, 2007). Data kuantitatif digunakan untuk mengetahui 
pengaruh penggunaan pengembangan aspek inkuiri terbimbing terhadap pemahaman konsep tentang cermin datar, sedangkan data kualitatif digunakan untuk mendukung hasil pemahaman konsep siswa. Penelitian dilakukan dalam lima tahap yaitu (1) pretest, (2) proses pembelajaran inkuiri terbimbing, (3) posttest, (4) analisis hasil pretest dan posttest secara kuantitatif dan kualitatif, (5) menyimpulkan hasil pembelajaran.

Subjek penelitian ini adalah siswa kelas VIII A, VIII C dan VIII D di salah satu SMP swasta di kota Malang. Berdasarkan pengalaman guru IPA di sekolah tersebut, subjek penelitian tergolong siswa yang memerlukan bimbingan lebih dalam proses pembelajaran, bukan hanya pada aspek kemampuan kognitif namun juga pada semangat belajar. Instrumen penelitian yang digunakan yaitu tes pemahaman konsep, lembar observasi dan lembar kerja siswa. Tes pemahaman konsep berupa tujuh tes pilihan ganda tentang konsep-konsep cermin datar. Telah divalidasi oleh dua dosen pembimbing untuk melihat kesesuain isi dan indikator. Selanjutnya instrumen digunakan untuk pretest dan posttest. Analisis instrumen mencakup dua hal, yaitu validitas dan reliabilitas butir soal. Hasil analisis validitas butir soal yang dinyatakan valid dianalisis reliabilitasnya menggunakan Cronbach's Alpha (Morgan dkk, 2005). Hasil perhitungan menggunakan SPSS 16.0 for Windows diperoleh nilai Cornbach's Alpha sebesar .273 yang termasuk dalam kategori rendah (Arikunto, 2009:75). Kemampuan yang diukur dalam tes pemahaman konsep diuraikan pada Tabel 1 berikut.

Tabel 1 Indikator Butir Soal

\begin{tabular}{ll}
\hline No. Soal & Indikator soal \\
\hline 1 & $\begin{array}{l}\text { Siswa dapat menyebutkan sifat bayangan yang dibentuk oleh cermin } \\
\text { datar }\end{array}$ \\
2 & $\begin{array}{l}\text { Siswa dapat menghitung jumlah bayangan yang dibentuk benda pada } \\
\text { dua cermin datar yang membentuk sudut jika diketahui sudutnya. }\end{array}$ \\
Siswa dapat menentukan sifat bayangan yang dibentuk cermin datar \\
berdasarkan gambar.
\end{tabular}

Analisis data dalam penelitian ini berupa analisis data kuantitatif dan kualitatif. Analisis data kuantitatif dengan grafik sebaran (scatter plot), statistik deskriptif, uji beda dan pengukuran kekuatan dampak menggunakan nilai d-effect size dan rata-rata nilai $\mathrm{N}$-Gain. Analisis data kualitatif didapatkan dari hasil wawancara.

Proses pembelajaran inkuiri terbimbing pada subbab cermin datar ditunjukkan sebagai berikut. 


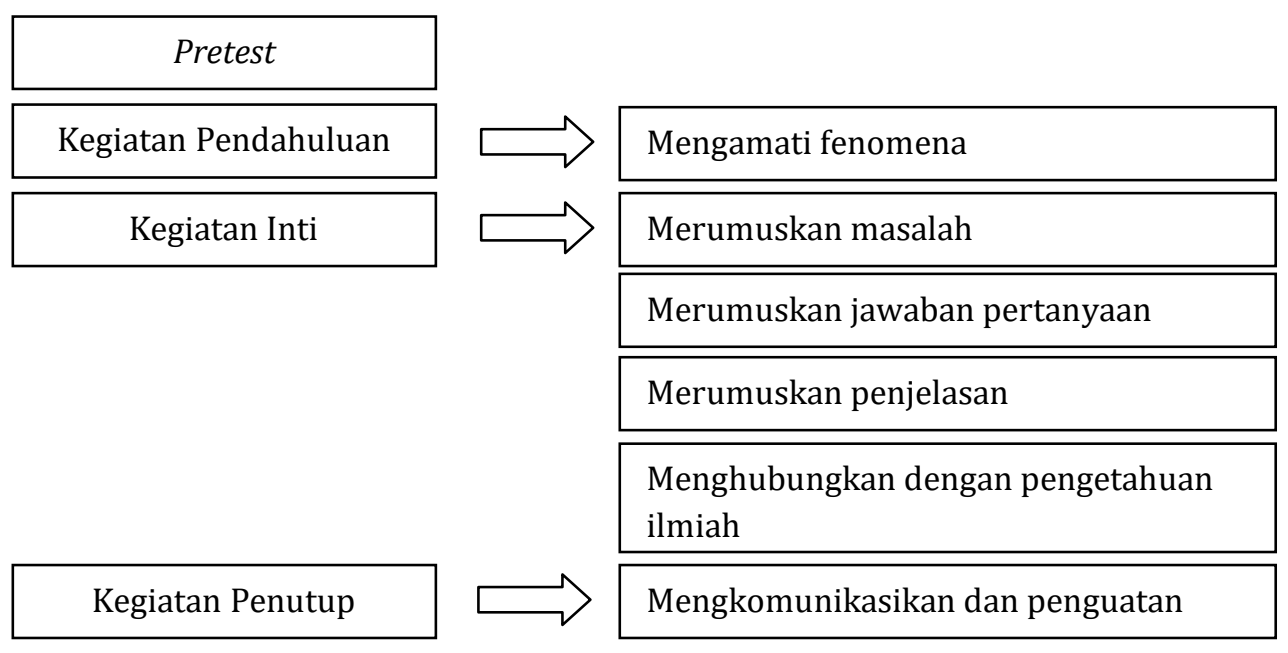

\section{Gambar 1 Tahapan Proses Pembelajaran Inkuiri Terbimbing Topik Pembentukan Bayangan pada Cermin Datar.}

Pembelajaran diawali dengan mengamati fenomena dengan sebuah cermin datar, kemudian meminta siswa melakukan demonstrasi bercermin dengan bantuan pertanyaanpertanyaan arahan. Kegiatan demonstrasi ini bertujuan untuk mengarahkan kegiatan siswa dalam pembentukan bayangan dan sifat-sifat bayangan yang dibentuk cermin datar seperti bentuk bayangan sama, tinggi bayangan sama dan tegak. Selanjutnya siswa diminta mendeskripsikan hasil demonstrasi yang dilakukan dan menuliskannya pada lembar kerja siswa. Berdasarkan hasil pengamatan tersebut, guru meminta siswa masalah berupa pertanyaan. Kegiatan ini bertujuan untuk menggali rasa ingin tahu siswa terhadap fenomena yang disajikan guru dan merangsang proses berpikir siswa. Dari beberapa pertanyaan yang muncul, guru mengarahkan pada rumusan masalah yang digunakan yaitu "Bagaimana proses pembentukan bayangan pada cermin datar?". Dari hasil rumusan masalah yang disepakati, guru memberikan pengarahan untuk merumuskan jawaban pertanyaan. Pada tahap ini, guru memberikan kesempatan kepada siswa untuk mengemukakan gagasannya atau idenya berkaitan dengan permasalahan yang sudah disepakati.

Untuk membuktikan jawaban sementara yang telah dibuat, guru mengarahkan siswa secara berkelompok untuk merumuskan penjelasan dengan melakukan analisis gambar pembentukan bayangan pada cermin datar yang ada pada pada lembar kerja siswa. Pada kegiatan ini siswa menentukan sinar pantul dari sinar datang yang sudah ditunjukkan dengan menggunakan prinsip hukum pemantulan. Dari sinar pantul yang sudah ditentukan, siswa memperpanjang sinar pantul dan menemukan titik potong dari perpanjangan dua sinar pantul.

Setelah selesai menggambarkan bayangan yang terbentuk, guru mengarahkan siswa untuk menghubungkan dengan pengetahuan ilmiah dengan menjawab pertanyaan dalam kolom diskusi. Dalam kegiatan ini, siswa menyimpulkan bahwa sifat bayangan yang dibentuk cermin datar yaitu tegak, jarak benda sama dengan jarak bayangan, dan tinggi benda sama dengan tinggi bayangan. Setelah semua siswa selesai menghubungkan dengan pengetahuan ilmiah, guru memberikan kesempatan kepada 
salah satu kelompok untuk mempresentasikan hasil diskusi ke depan kelas pada kegiatan mengkomunikasikan dan penguatan. Pembelajaran diakhiri dengan diberikan penguatan oleh guru tentang hasil pengamatan yang dilakukan diawal pembelajaran dengan kesimpulan hasil diskusi. Kemudian pembelajaran diakhiri dengan menyimpulkan hasil pembelajaran denga teknik tanya jawab.

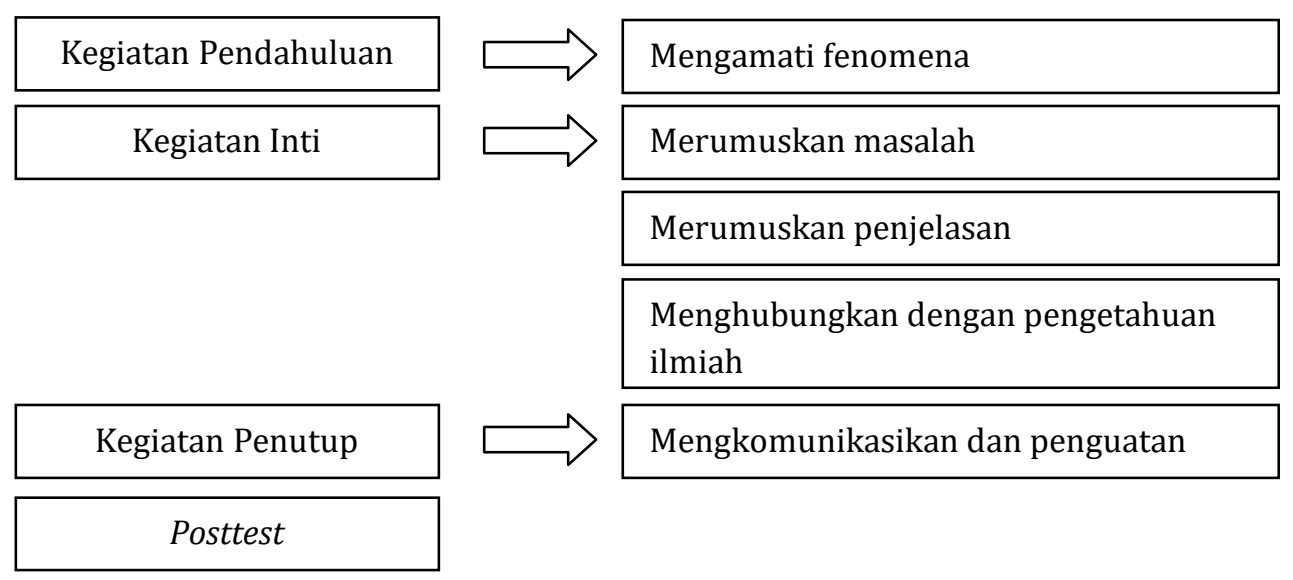

\section{Gambar 2 Tahapan Proses Pembelajaran Inkuiri Terbimbing Topik Jumlah Bayangan yang Dibentuk Dua Cermin Datar yang Membentuk Sudut.}

Kegiatan diawali dengan mengamati fenomena sebuah gambar rumah cermin. Setelah mengamati bayangan yang dibentuk pada rumah cermin, guru meminta salah satu siswa maju untuk mengamati jumlah bayangan yang dibentuk dua cermin datar yang membentuk sudut. Setelah salah satu siswa mengamati demonstrasi, guru menampilkan gambar seperti pada demonstrasi yang dilakukan. Kegiatan ini bertujuan untuk menggali pengetahuan awal siswa pada banyaknya bayangan yang dibentuk dua cermin datar. Hasil pengamatan siswa ini dituliskan pada lembar kerja siswa. Dari gambar yang ditampilkan, guru meminta siswa merumuskan pertanyaan sesuai hasil pengamatan. Dari beberapa pertanyaan yang sudah dikemukakan siswa, guru mengarahkan untuk menyimpulkan pertanyaan yang digunakan yaitu "Bagaimana menentukan jumlah bayangan yang dibentuk dua cermin datar yang membentuk sudut?". Untuk menjawab pertanyaan yang sudah dibuat, guru mengajak siswa melakukan percobaan secara berkelompok. Percobaan ini bertujuan untuk menemukan rumus jumlah bayangan yang dibentuk oleh dua cermin datar. Guru tetap memberikan arahan seperti pada pada peletakan cermin dan busurnya yang harus sesuai serta pengamatan yang hanya dapat diamati pada satu sisi saja.

Setelah pengambilan data selesai, guru meminta siswa menghubungkan dengan pengetahuan ilmiah dengan mengerjakan pertanyaan diskusi dalam lembar kerja siswa. Pembelajaran diakhiri dengan kegiatan mengkomunikasikan dan penguatan. Setelah semua kelompok selesai berdiskusi, guru meminta satu kelompok menuliskan jawabanya dipapan tulis. Guru memberikan kesempatan kepada kelompok yang mempunyai jawaban berbeda mengemukakan jawabannya. Pembelajaran diakhiri dengan guru memberikan penguatan dari hasil data yang diperoleh siswa dan menyimpulkan hasil pembelajaran. 


\section{Hasil dan Pembahasan}

\section{Pemahaman Konsep Siswa pada Subbab Cermin Datar}

Hasil pretest dan posttest dianalisis menggunakan grafik sebaran (Scatter plot). Grafik sebaran (Scatter plot) menunjukkan hasil skor pretest dan posttest diatas ratarata seperti ditunjukkan pada Tabel 2 berikut.

Tabel 2 Hasil Skor Pretest dan Posttest diatas rata-rata

\begin{tabular}{lll}
\hline Skor & Frekuensi (Siswa) & Presentase (\%) \\
\hline Skor pretest diatas rata-rata & 34 & 38,6 \\
Skor posttest diatas rata-rata & 34 & 38,6 \\
\hline
\end{tabular}

Hasil perhitungan statistik deskriptif menunjukkan nilai rata-rata pretest 1.3523 sedangkan posttest 4.0568. Nilai skewness pada pretest .624 dan posttest -.076 . Nilai skewness tersebut berada pada rentang -1 sampai dengan +1 sehingga data dianggap terdistribusi normal. Selanjutnya data tersebut dapat diuji beda dengan menggunakan paired sample t-test dengan menggunakan SPSS 16.0 for Windows dengan hasil uji $t$-tes 2-tailed .000. Nilai signifikansi tersebut kurang dari 0,01 sehingga dapat disimpulkan bahwa perbedaan nilai pretest dan posttest adalah signifikan. Sehingga dapat diartikan bahwa pembelajaran inkuiri terbimbing dapat meningkatkan pemahaman konsep siswa pada materi cermin datar.

Kekuatan peningkatan pretest dan posttest diukur menggunakan $d$-effect size dan rata-rata nilai Gain ternormalisasi. Nilai $d$-effect size diperoleh 2,32 yang termasuk dalam kategori tinggi sekali. Nilai $\mathrm{N}$-Gain diperoleh 0,47 yang termasuk dalam kategori medium atas. Peningkatan pemahaman konsep siswa juga ditunjukkan dari hasil analisis butir soal pretest dan posttest yang ditunjukkan pada gambar 3 berikut.

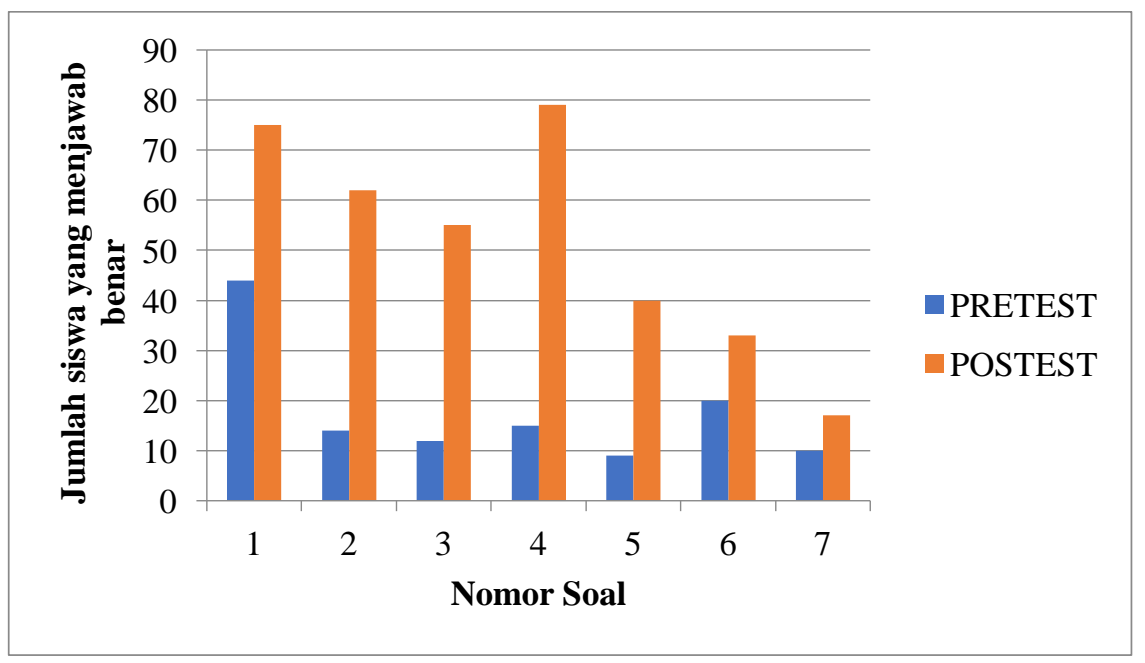

\section{Gambar 3 Histogram Jumlah Siswa yang Menjawab Benar pada Setiap Butir Soal}

Dari histogram tersebut menunjukkan bahwa rata-rata terjadi kenaikan jumlah siswa yang menjawab benar dari tahap pretest ke posttest. Dari tujuh soal yang diberikan, kenaikan tertinggi jumlah siswa yang menjawab benar yaitu pada soal 
nomor 4. Pada pretest terdapat 14 siswa yang menjawab benar sedangkan ketika posttest sebanyak 78 siswa menjawab benar dan ada 10 siswa yang masih menjawab salah. Hasil analisis yang dilakukan dengan metode wawancara pada siswa yang masih menjawab salah diperoleh keterangan bahwa siswa yang masih menjawab salah dikarenakan kurang ketelitian dari siswa.

Kenaikan terendah pada soal nomor 7 yaitu pada pretest terdapat 9 siswa yang menjawab benar sedangkan ketika posttest sebanyak 17 siswa menjawab benar. Walaupun jumlah siswa yang menjawab benar sudah meningkat dari pretest ke posttest namun kenaikannya masih relatif sedikit. Hasil analisis yang dilakukan dengan metode wawancara pada siswa yang masih menjawab salah diperoleh keterangan bahwa siswa masih kesulitan menggambarkan pembentukan bayangan pada cermin datar menggunakan sinar-sinar pantul, selain itu siswa juga kesulitan mengaplikasikan hukum pemantulan pada pembentukan bayangan pada cermin datar.

Hasil analisis butir soal yang dilakukan menjunjukkan bahwa terjadi peningkatan pemahaman siswa setelah dilakukan pembelajaran inkuiri terbimbing walaupun masih terdapat kekurangan dalam beberapa hal. Namun apabila dihubungkan dengan nilai N-Gain yang diperoleh dengan kategori medium atas pembelajaran cermin datar menggunakan inkuiri terbimbing dapat merubah konsep siswa dari yang kurang benar menjadi benar. seperti dinyatakan oleh Meidahrianti (2014) menyatakan bahwa siswa benar-benar memahami konsep dengan adanya perubahan konseptual, baik yang memperluas konsep ataupun meluruskan konsep yang tidak tepat. Sehingga, pembelajaran inkuiri terbimbing dapat digunakan sebagai alternatif pembelajaran yang dapat meningkatkan pemahaman konsep siswa khususnya pada subbab cermin datar. Diperkuat juga oleh Wenning (2011) bahwa pembelajaran melalui inkuiri membuat siswa belajar sains dengan pemahaman yang lebih baik.

\section{Simpulan}

\section{Kesimpulan}

Dari hasil penelitian disimpulkan bahwa pengembangan aspek pembelajaran inkuiri terbimbing dapat meningkatkan pemahaman konsep siswa pada subbab cermin datar. Kekuatan peningkatan pemahaman konsep diperoleh nilai $d$-effect size yaitu 2,32 yang termasuk dalam kategori tinggi sekali dan nilai $\mathrm{N}$-Gain diperoleh 0,47 yang termasuk dalam kategori medium atas. Peningkatan pemahaman konsep ini didukung aspek-aspek dalam pembelajaran inkuiri terbimbing yaitu (1) mengamati fenomena, (2) merumuskan masalah, (3) merumuskan jawaban pertanyaan, (4) merumuskan penjelasan, (5) menghubungkan dengan pengetahuan ilmiah, (6) mengkomunikasikan dan penguatan.

\section{Saran}

Pembelajaran inkuiri terbimbing memerlukan waktu yang cukup lama untuk mengarahkan siswa menemukan konsep yang menjadi tujuan pembelajaran. Sehingga, konsep yang dibelajarkan sebaiknya tidak terlalu luas dan dipandu dengan lembar kerja siswa yang jelas. Materi pembentukan bayangan pada cermin datar ini termasuk 
materi yang abstrak dipelajari untuk siswa SMP, sehingga diperlukan bimbingan tiap kelompok untuk menjelaskan konsep yang dipelajari. Dan juga guru sebaiknya melakukan pengecekan ulang pada data yang diperoleh siswa selama analisis gambar atau percobaan berlangsung dan memastikan masing-masing siswa paham dengan konsep yang dipelajari yang dengan melakukan tanya jawab.

\section{Daftar Rujukan}

Abidin, Y. 2014. Desain Sistem Pembelajaran Dalam Konteks Kurikulum 2013. Bandung: PT Refika Aditama.

Agnes, D., Kaniawati, I., \& Danawan, A. (2015). Analisis Deskriptif Tes Tiga Tingkat Materi Optika Geometri dan Alat Optik. Prosiding Simposium Nasional Inovasi dan Pembelajaran Sains, 2015, 597-600.

Arikunto, S. (2009). Dasar-dasar Evaluasi Belajar. Jakarta: PT Bumi Aksara.

Creswell, J. W., \& Clark, V. L. P. (2017). Designing and conducting mixed methods research. Sage publications.

Hamdani, D., Kurniati, E., \& Sakti, I. (2012). Pengaruh model pembelajaran generatif dengan menggunakan alat peraga terhadap pemahaman konsep cahaya kelas VIII di SMP Negeri 7 Kota Bengkulu. Exacta, 10(1), 79-88.

National Research Council. (2012). A framework for K-12 science education: Practices, crosscutting concepts, and core ideas. National Academies Press.

Meidahriati., Zulherman \& Taufiq. (2014). Pengaruh Strategi Pembelajaran Konflik Kognitif Terhadap Perubahan Konseptual Siswa pada Materi Listrik Dinamis di SMA Negeri 1 Tanjung Batu. Jurnal Inovasi dan Pembelajaran Fisika. 1 (1): 48 - 55.

Morgan, G. A., Leech, N. L., Gloeckner, G. W., \& Barrett, K. C. (2004). SPSS for introductory statistics: Use and interpretation. Psychology Press.

Penyusun, T. (2013). Peraturan Menteri Pendidikan dan Kebudayaan Nomor 65 Tahun 2013 Tentang Standar Proses Pendidikan Dasar dan Menengah. Jakarta: Kemendikbud.

Rustaman, N. Y. (2005, July). Perkembangan penelitian pembelajaran berbasis inkuiri dalam pendidikan sains. In Makalah dipresentasikan dalam Seminar Nasional II Himpunan Ikatan Sarjada dan Pemerhati Pendidikan IPA Idonesia Bekerjasama dengan FPMIPA. Universitas Pendidikan Indonesia, Bandung (pp. 22-23).

Saputri, D. F., \& Nurussaniah, N. (2015, October). Penyebab miskonsepsi pada optika geometris. In Prosiding Seminar Nasional Fisika (E-Journal) (Vol. 4, pp. SNF2015-IV).

Slack, A. B. (2007). Preservice science teachers' experiences with repeated, guided inquiry.

Sutopo. (2014). Miskonsepsi pada Optik Geometri dan Remidiasinya. Journal TEQIP, V (2): 356-368.

Umrotun, U. (2012). Peningkatan Kemampuan Pemahaman Konsep Optik Melalui Teknik Inkuiri Terbimbing Peserta Didik Kelas VIII Semester Genap Tahun Ajaran 2011/2012. Jurnal Penelitian Pembelajaran Fisika, 3(1).

Wenning, C. J. (2005). Levels of inquiry: Hierarchies of pedagogical practices and inquiry processes. In J. Phys. Teach. Educ. Online.

Wenning, C. J. (2011). Experimental inquiry in introductory physics courses. Journal of Physics Teacher Education Online, 6(2), 2-8. 